\title{
Dynamic Hijaiyah Braille Display With Voice Features and Android Integrated as a Media for Introduction to Arabic Letters for Blind Children
}

\author{
Muhamad Rafi Anggara*, Arief Khairi Irawan, \\ Lukman Arif Purwanto, Dandhi Kuswardhana \\ Faculty of Technology and Vocational Education \\ Universitas Pendidikan Indonesia \\ Bandung, Indonesia \\ *muhamadrafianggara@student.upi.edu
}

\author{
Adhit Cahyo Prasetyo \\ Faculty of Education \\ Universitas Pendidikan Indonesia \\ Bandung, Indonesia
}

\author{
Egawan \\ Faculty of Economics and Business Education \\ Universitas Pendidikan Indonesia \\ Bandung, Indonesia
}

\begin{abstract}
The provision of learning media for blind people is one of the things that must be considered for equality in educating the nation through inclusive education. One of the media that can be used by blind children in learning to recognize braille characters is Refreshable Braille Display media that can work according to instructions from the user. However, the media is still difficult to find because they have to order abroad for around 3600 euros, the equivalent of about 53 million rupiahs. In addition, this device is limited to the Latin writing system's letters and punctuation marks. It cannot be used to generate Arabic letters or the so-called hijaiyah characters. This study aims to produce Dynamic Hijaiyah Braille Display media with voice features and integrated android, which can be used as a medium for recognizing Arabic letters for blind children. Therefore, as the solution, we offer the Dynamic Hijaiyah Braille Display media, which has the advantage of Arabic letters in the form of braille characters and can sound according to the letters pressed. Learning can also be monitored by parents or teachers virtually through the android application. In this research, an electronic system is designed to accommodate two braille character cells for Arabic letters and their punctuation. The device is also equipped with voice features and an integrated android application. This system was tested with the results of being able to generate two patterns with a functioning solenoid and integration with Android devices using the Firebase platform. Furthermore, the voice feature can be operated properly according to the hijaiyah character being learned.
\end{abstract}

Keywords-android application, blind children, dynamic hijaiyah braille display, voice features

\section{INTRODUCTION}

Information and communication technology has now digitalized almost every aspect of human life. Buying and selling, social interaction, government bureaucracy, and learning technology is no exception. Learning media that also has the impact of information and communication technology are learning media for blind people. The advancement of electronic technology has provided a choice of new learning media for blind people in a lesson [1]

One of the media that can be used by blind people to reach information is a refreshable braille display. This media is a device that can display braille characters dynamically and can change according to instructions given by the user [1]. In Indonesia, if you want to get a refreshable braille display device that consists of 24 cells as shown in Figure 1, you have to pay around 3600 euros or the equivalent of around 53 million rupiahs [2]. In fact, visually impaired persons, especially in Indonesia, mostly come from the lower middle class, so the price must be ordered from abroad because it is not yet widely available on the market.

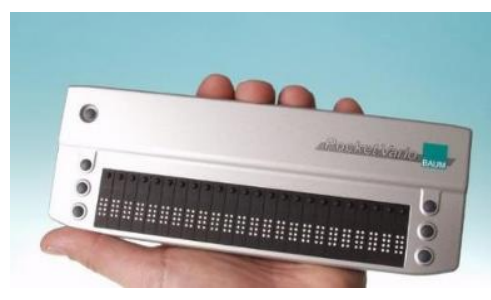

Fig. 1. Refreshable braille display [2]. 
Indonesia itself is a country with a majority of Muslims with a total population of 204 million people, namely 264 million including around 3.75 million blind people [3], who of course need to learn to read the Koran. However, there is currently no refreshable braille display that features as a learning media for the Qur'an.

Refreshable braille displays can be innovated according to the conditions and learning needs of blind students, in this case, recognizing hijaiyah letters. This is the focus of this research, namely making a learning tool to recognize hijaiyah letters for blind students who have voice features and are integrated with the Android system.

\section{LITERATURE REVIEW}

\section{A. Braille Letters}

Braille is currently an international writing system for people with visual impairments. Braille was first discovered by Louis Braille in 1825 which contains six dots (height $=0.5$, distance between dots $=2.5 \mathrm{~mm}$ ) wherein the braille setting the dots will represent the letters of the alphabet [4].

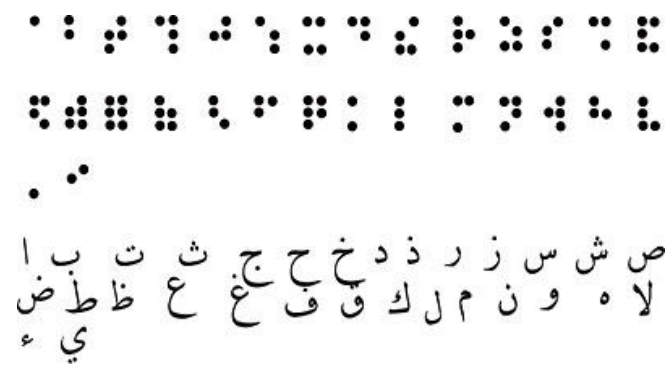

Fig. 2. Conversion of braille hijaiyah letters [5].

Specifically, in figure 2 it can be described as consisting of two columns and three rows, where the pattern of the emergence dots can show 63 different meanings indicating letters, numbers, or punctuation marks [6]. While the braille letters in Arabic or hijaiyah can be seen in the following picture,

\section{B. Overview of Target Communities}

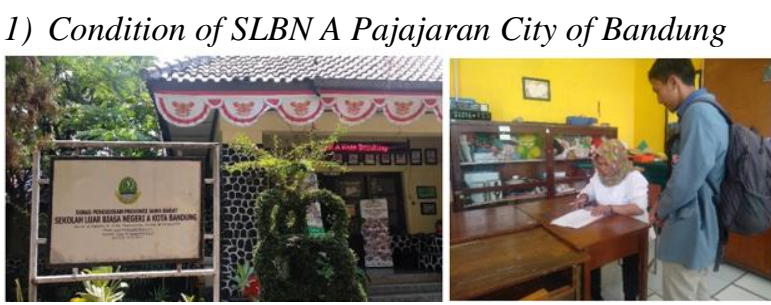

Fig. 3. Condition of SLBN A Pajajaran Bandung.

SLBN A Pajajaran Kota Bandung is the oldest formal school for the blind in Southeast Asia (Figure 3). The levels of education held at this school include TK-LB, SD-LB, SMPLB, and SMA-LB. There were 77 students with an accumulation of 42 males and 35 females with an average of
18 people at each level. The intelligence developed in this school leads to spiritual, emotional and social, intellectual, and kinesthetic intelligence [7]. One of the efforts made in developing the spiritual intelligence of students is by introducing them to the Koran. According to one teacher who teaches at SLBN A Pajajaran, Bandung, learning to read the Koran is carried out after every zuhr prayer in the congregation. Students who have not been able to read the Koran are trained to use conventional braille iqro books. This is a separate obstacle, especially when distance learning is required during the Covid-19 outbreak.

2) Condition of SLBN A Citeureup Cimahi City: SLBN A Citeureup is a fraction of the SLBN A Pajajaran Bandung City since 1986. This special school has several types of specialties including children with visual impairments (blind), children with hearing impairments (deaf), children with intellectual disabilities (mental retardation), children with impairments motor (disabled), and children with autism. The number of students in this school is 113 boys and 74 girls. There are 45 students with visual impairment alone [7].

In this school, there is a syllabus prepared by the SLBN A Citeureup teaching staff for learning the Koran, starting from the introduction of letters, reading marks, recitation to its history. However, learning still uses the braille iqro book for basic lessons of the Koran. Just like SLBN A Pajajaran, this school also has difficulties when it comes to conducting distance learning. See figure 4 bellow.

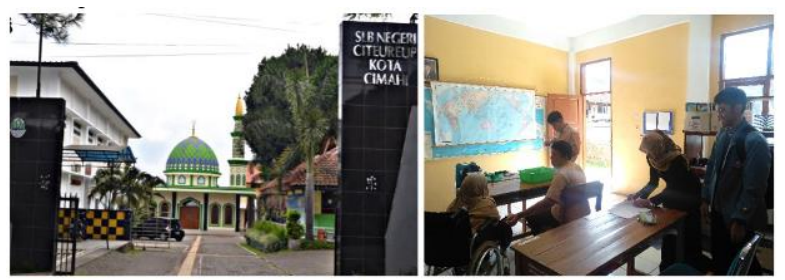

Fig. 4. Condition of SLBN A Citeureup Cimahi City.

\section{Main Components}

\section{1) $\operatorname{ESP} 32$}

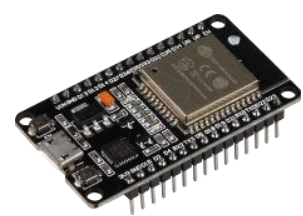

Fig. 5. ESP2 [8]

ESP2 (figure 5) was first announced by Espressif System, which is the result of an upgrade from its predecessor, the ESP8266 [8]. The advantages of the ESP32 are that it is cheaper, requires low power for a microcontroller chip that is integrated with $\mathrm{Wi}-\mathrm{Fi}$, has dual Bluetooth capabilities, and also features a power-saving feature that makes it possible to adapt even with various tasks and commands [9]. ESP32 can connect to mobile devices and the internet of things (IoT) application. 
The characteristics of ESP32 can be a consideration for using it in a learning environment, especially in making learning media.

2) Relay module 6 channel: Relay module (figure 6) is a collection of several relays that are assembled on a PCB (printed circuit board) [10]. Use relay modules to control switched devices. By integrating relay outputs into an intrusion [11]

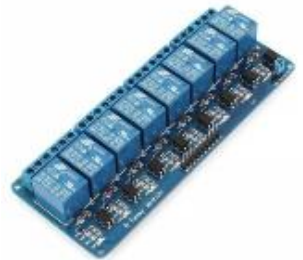

Fig. 6. Relay module 6 channel [11]

3) Mini solenoid 12V: A solenoid (figure 7) is one type of coil made of long cable which is tightly wound and it can be assumed that its length is much larger than its diameter [12]. This section functions as an actuator. The principle of the solenoid itself will work as a lock and will be active when given a voltage of $12 \mathrm{~V}$. Inside the solenoid, there is a wire coiled to the iron core. When an electric current flows through this wire, a magnetic field occurs to produce energy that will attract the iron core in [13]. In designing the dynamic hijaiyah braille display, the solenoid type used is the solenoid push.

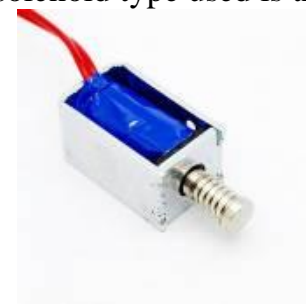

Fig. 7. Solenoid push [12]

\section{METHODS}

The design of the dynamic hijaiyah braille display system uses an experimental method, namely by conducting a direct experiment during the construction of the dynamic hijaiyah braille system. In making this system, there are several stages, namely needs analysis, designing hardware and software, and testing the system. This stage can be seen in figure 8 .

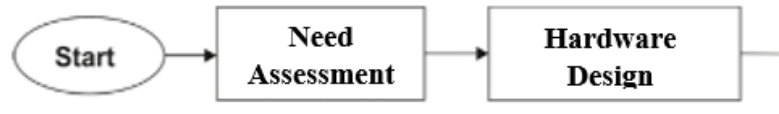

Fig. 8. Research methods.

\section{A. Needs Analysis of Tool Use}

In implementing this program, the first stage carried out is surveying the target schools. After that, the next stage is to observe and see directly the conditions of the problems of learning to read the Koran in these schools so that an analysis of the need for the use of tools for blind students is shown in Figure 9 below:

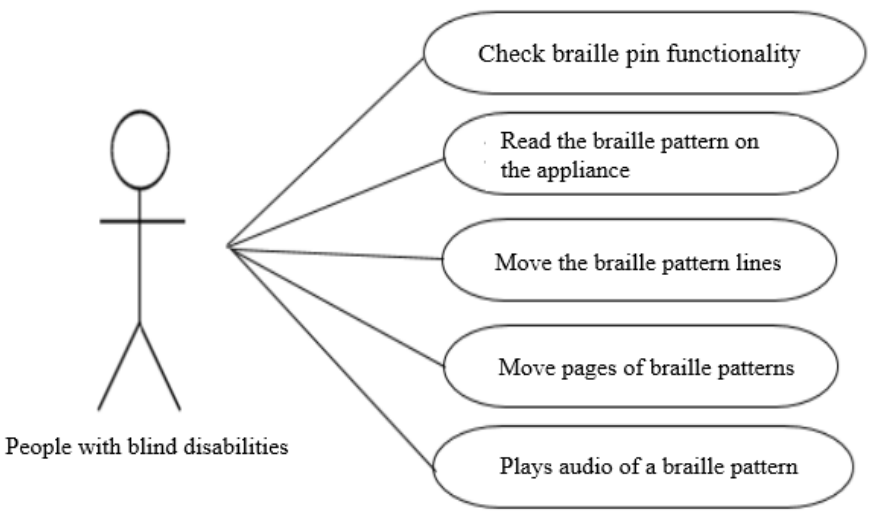

Fig. 9. Use case diagram of the tool.
After observing, the researchers determined the target schools, namely SLBN A Pajajaran Bandung City and SLB Negeri A Citeureup. The next stage is to ask the principal for permission to help teachers who teach basic Koran reading by applying the Dynamic Hijaiyah Braille Display tool which functions as a basic Koran reading learning medium for blind students. After that, the principal together with several teaching teachers gathered to socialize the planning of making learning media for Dynamic Hijaiyah Braille Display as well as test opinions with the teaching teachers. Table 1 shows the identification of the needs of the target community and the alternatives offered.

TABLE I. IDENTIFICATION AND ALTERNATIVE SOLUTIONS TO PROBLEMS

\begin{tabular}{|c|l|}
\hline \multicolumn{1}{|c|}{ Identification } & \multicolumn{1}{c|}{ Alternative } \\
\hline Conventional learning media & Dynamic Hijaiyah Braille Display \\
- Using touch & - Use sound and touch features \\
- The mass is heavy & - Lightweight and ergonomic \\
- Requires multiple sheets & - Using only one medium \\
of braille paper & - Easy maintenance \\
- Damaged easily & \\
\hline
\end{tabular}




\section{B. Hardware Design}

The next stage is to procure the materials needed for implementation. The components that are composed of the dynamic hijaiyah braille display are as follows in table 2:

TABLE II. LIST OF COMPONENTS

\begin{tabular}{|c|c|c|}
\hline \multirow{2}{*}{ No } & \multicolumn{2}{|c|}{ Component of the Tool } \\
\hline & Component & Qty \\
\hline 1 & Relay Module 6 Channel & 1 \\
\hline 2 & DF Player & 1 \\
\hline 3 & Speaker & 2 \\
\hline 4 & SD Card 6GB & 1 \\
\hline 5 & ESP32 & 1 \\
\hline 6 & Jumper Female to Male & 1 Pack \\
\hline 7 & Jumper Female to Female & 1 Pack \\
\hline 8 & Adaptor $12 \mathrm{~V} 2.5 \mathrm{~A}$ & 1 \\
\hline 9 & Solenoid push 5V & 6 \\
\hline 10 & Saklar & 1 \\
\hline 11 & PCB & 2 \\
\hline 12 & FCP 1 x $40 \mathrm{M}$ & 4 \\
\hline 13 & FCP $1 \times 40 \mathrm{~F}$ & 3 \\
\hline 14 & Infra Board & 2 \\
\hline 15 & Korean glue & 1 \\
\hline 16 & Anam Electronics & 1 \\
\hline 17 & Anam Electronics & 1 \\
\hline 18 & Anam Electronics & 1 \\
\hline 19 & Glue Burn & 1 \\
\hline 20 & Battery Holder & 1 \\
\hline 21 & Lithium battery & 4 \\
\hline 22 & BMS 3S & 1 \\
\hline 23 & Rainbow Cable & 3 \\
\hline 24 & Terminal block & 3 \\
\hline 25 & Pin Header Female & 5 \\
\hline 26 & Pin Header Male & 5 \\
\hline 27 & Male to Male Cable & 1 \\
\hline 28 & Button & 4 \\
\hline
\end{tabular}

The process of making this design uses Solidworks as three-dimensional software. The initial stage is to determine the parts that are composed of the equipment, such as a braille bin size set according to the standard size [14] (Figure 10), and the mechanical details of the outer (Figure 11) and inner display (Figure 12).

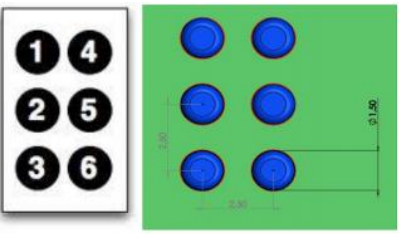

Fig. 10. Braille pin design on the device.

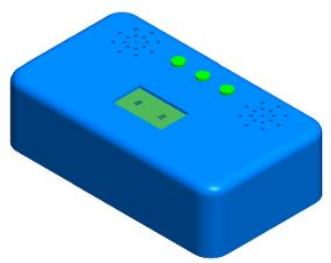

Fig. 11. Design of the external display of the device.

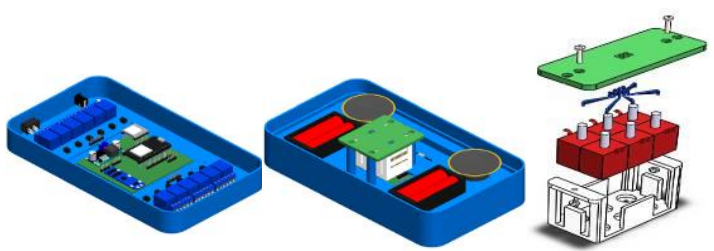

Fig. 12. Display design in the device.

\section{Software Design}

That hardware will be integrated with applications on Android using a microcontroller. it starts by displaying a page which will be redirected to the main page containing the names of the product users. If we select a user name, the application will redirect to a page where we can find out user information such as name, class, reading progress, and tests that have been carried out. In addition, on the main page, there is a button connected to the learning progress information as a reference for the teacher or parents. Figure 13 shows the design flow of the application to be made.

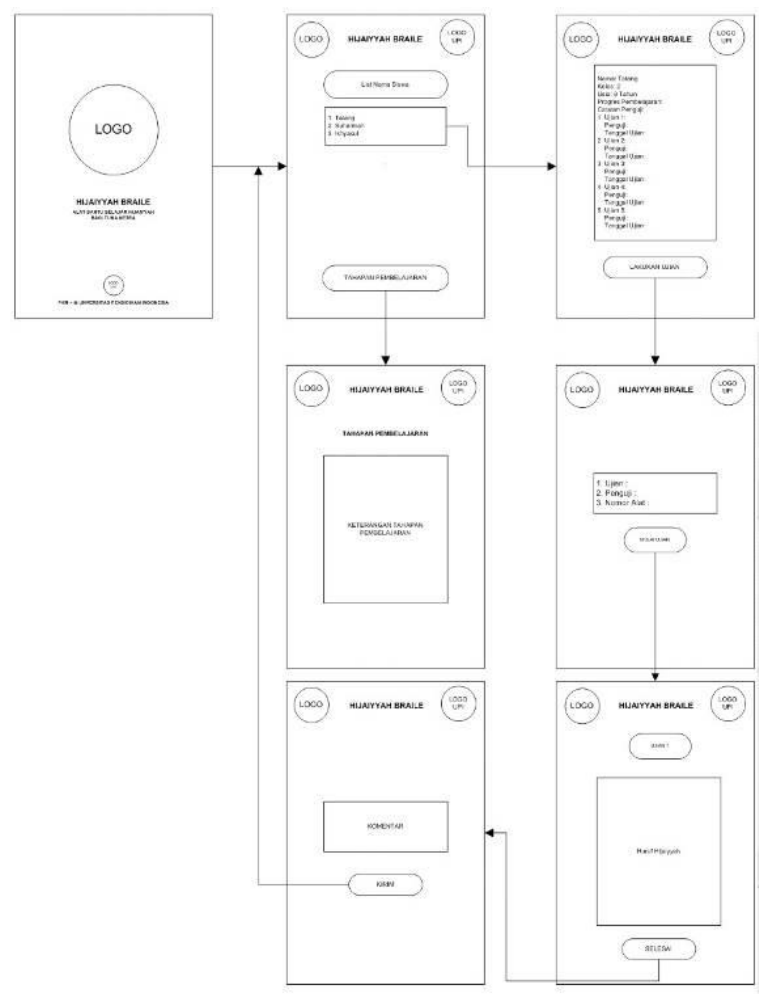

Fig. 13. Application flow design.

The application functions for monitoring using a relationship through a database made by Google, the database will later be retrieved by the application. 


\section{RESULTS AND DISCUSSION}

After the needs analysis and design stages have been carried out, then a trial of how the device works is carried out. The workings of the device are shown in Figure 14.

The ESP32 gets its energy source from an 18650 battery which is connected to the charger module so that it can be charged. The voltage of the four 18650 batteries is $14.1 \mathrm{~V}$, which is sufficient to provide voltage to the solenoid in the braille character. Before entering the ESP32, a step-down regulator module is given so that the voltage drops to $3.3 \mathrm{~V}$ according to the ESP32 reference voltage. So there are three buttons, the next, the previous, and the play buttons. When the play button is pressed, the ESP32 will give an order to the braille character in which there are six solenoids, to be active according to the braille hijaiyah character. At almost the same time, ESP32 also sends commands to DFPlayer to play audio that matches hijaiyah braille characters displayed in braille characters. Audio can be heard by the user through the speakers. And at almost the same time ESP32 also sends character data that has been displayed to the android application. The Next and previous buttons are for changing the character you want to display. How it works can be seen on figure 14 .

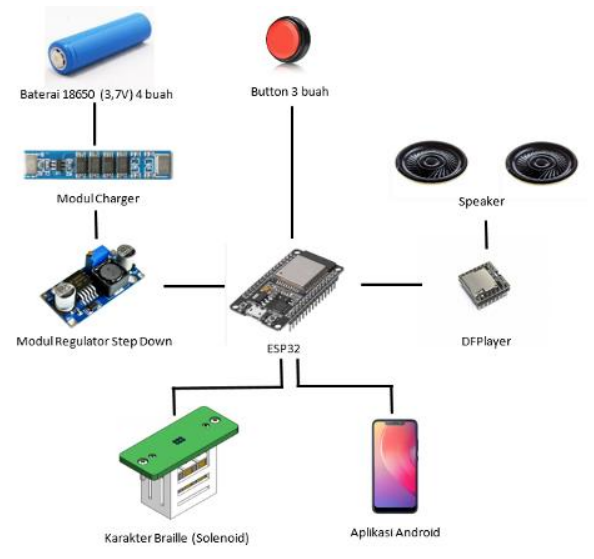

Fig. 14. How it works.

Furthermore, from the scheme that has been designed, a Printed Circuit Board is made as a form of design implementation. Figure 15 shows the PCB display of this device.

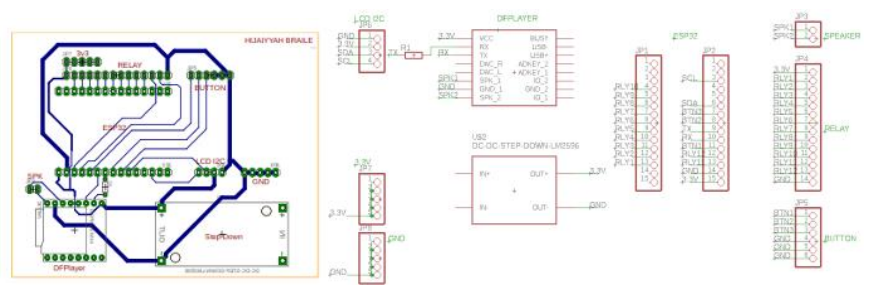

Fig. 15. PCB display.

\section{A. Hardware Testing}

The first test is the next line feature and the sound in the document. The treatment given to the device in this test is to press the next line button to the end of the document content. Figure 16 shows a design view from the top of the device.
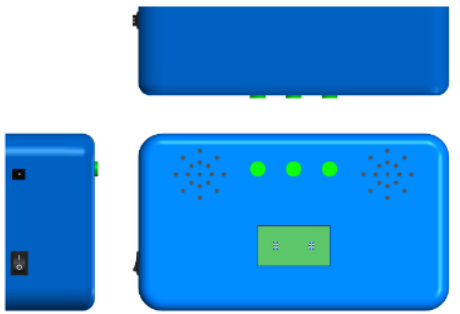

Fig. 16. Top view of the device.

At the same time, a voice feature test was also carried out by pressing the play sound button and then listening directly to the resulting sound quality. From the test, it can be observed that the sound cannot appear as desired. Table 3 shows the test results for the next line and voice features with examples of the five hijaiyah letters in society.

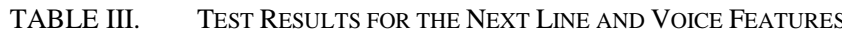

\begin{tabular}{|c|c|c|c|c|c|c|c|c|c|c|c|c|c|}
\hline \multirow{2}{*}{ Words } & \multirow{2}{*}{$\begin{array}{c}\text { Hijaiyah } \\
\text { Letter }\end{array}$} & \multirow{2}{*}{ Harakat } & \multicolumn{6}{|c|}{ Braille 1} & \multicolumn{4}{|c|}{ Braille 2} & \multirow{2}{*}{ Voice } \\
\hline & & & 1 & 2 & 3 & 4 & 5 & 6 & 12 & 2 & 45 & 6 & \\
\hline بَ & ba & fathah & 1 & 1 & 0 & 0 & 0 & 0 & 0 & 10 & \begin{tabular}{l|l}
0 & 0
\end{tabular} & 0 & BA \\
\hline ت & ta & kashrah & 0 & 1 & 1 & 1 & 1 & 0 & 1 & $0|0|$ & \begin{tabular}{l|l}
0 & 1
\end{tabular} & 0 & TI \\
\hline جُ & jim & dhammah & 0 & 1 & 0 & 1 & 1 & 0 & 1 & & 0 & 1 & $\mathrm{JU}$ \\
\hline ك) & kaf & fathah & 1 & 0 & 1 & 0 & 0 & 0 & 0 & 10 & 0 & 0 & KA \\
\hline لِ & lam & kashrah & 1 & 1 & 1 & 0 & 0 & 0 & 1 & 00 & \begin{tabular}{l|l}
0 & 1
\end{tabular} & 0 & LI \\
\hline
\end{tabular}

\section{B. Software Testing}

The connectivity test is done by connecting the device with Android via IoT. This Android integrated device feature is not functioning properly due to a program error. The appearance of this application can be seen in Figure 17 below.

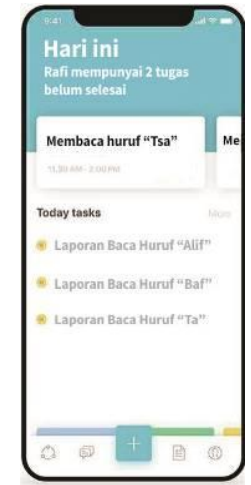

Fig. 17. Display android application. 


\section{CONCLUSIONS}

Based on the data analysis carried out in the previous chapter, the following conclusions can be drawn that the button module as a navigation feature can function properly, the connectivity with Android devices through the IoT feature has not been functioning properly, and the speakers can sound well when this feature is activated via the voice play button.

\section{ACKNOWLEDGMENT}

This journal and the research behind it would not have been possible without the extraordinary support of our advisors. His enthusiasm, knowledge, and meticulous attention to detail have inspired and made our work as well as for TVeT which has provided us with the opportunity to present the results of the writing of this journal.

\section{REFERENCES}

[1] Anonymous, Situasi Penyandang Disabilitas. Jakarta, 2004.

[2] V. Kartha, D.S. Nair, S. Sreekant, P. Pranoy, and P. Jayaprakash, "DRISHTI-A gesture controlled text to braille converter," In 2012 Annual IEEE India Conference (INDICON) (pp. 335-339), 2012.

[3] Badan Pusat Statistik, Indonesia - Sensus Penduduk 2010. Jakarta, 2010.

[4] J. Jiménez, J. Olea, J. Torres, I. Alonso, D. Harder, and K. Fischer, "Biography of Louis Braille and Invention of the Braille Alphabet," Survey of Ophthalmology, vol. 54, no. 1, pp. 142-149, 2009.
[5] S.N. Ismawati, "Media Permainan Ular Tangga Modifikasi terhadap Kemampuan Berhitung Penjumlahan Anak Tunanetra pada Sekolah Luar Biasa,” Jurnal Pendidikan Khusus, Vol. 9, No. 3, 2017.

[6] Diono, Buletin Jendela Data \& Informasi Kesehatan. Jakarta, 2014.

[7] T.M. Pynkyawati, Desain Sirkulasi Sekolah Luar Biasa "A" Negeri Bandung terhadap Kemudahan Pengguna Penyandang Tunanetra. Jakarta: Safiria Insania Press, 2018.

[8] ESP32 Technical Reference Manual, Version 2.8, Espressif system, \#101, Block2, 690 Bibo Road, Zhangjiang High-Tech Park, Pudong, Shanghai, China 201203, 2018.

[9] S.B. Biswas, and M.T. Iqbal, "Solar water pumping system control using a low cost ESP32 microcontroller," In 2018 IEEE Canadian conference on electrical \& computer engineering (CCECE) (pp. 1-5). IEEE, 2018.

[10] S. Tomasua, D. Triyanto, and I. Nirmala, "Sistem kendali dan monitoring penggunaan peralatan listrik di rumah menggunakan Raspberry Pi dan Web Service," Coding Jurnal Komputer dan Aplikasi, Vol. 4, No. 3, 2016.

[11] D. Yadav, Y. Singh, and H. Gupta, "Controlling of Relay using Raspberry Pi Via Internet for Home Automation,” International Journal of Advanced Research in Engineering and Technology, Vol. 9, No. 1, 2018.

[12] W. Winarto, A. Setiawan, and R. Lim, "Sistem Peminjaman Loker Otomatis Menggunakan QR Code dan Arduino," Jurnal Infra, Vol. 8, No. 1, pp. 272-277.

[13] H. Guntoro and Y. Somantri, "Rancang bangun magnetic door lock menggunakan keypad dan solenoid berbasis mikrokontroler arduino uno," electrans, Vol. 12, No. 1, pp. 39-48, 2013.

[14] V. Papadimitriou and V. Argyropoulos, "The effect of hand movements on braille reading accuracy," International Journal of Educational Research, Vol. 85, pp. 43-50, 2017. 